\title{
ARTICLES
}

\section{THE KNOWLEDGE REGARDING FOOT CARE AMONG THE DIABETES PATIENTS}

Mr. Kailash Chandra Saini* I Dr. Rajendra Prasad Sharma**

*Associate Professor, Apex University, Jaipur, Rajasthan, India.

**Associate Professor, Mahatma Gandhi Nursing College, Jaipur, Rajasthan, India.

DOI: http://doi.org/10.47211/idcij.2021.v08i03.013

\section{ABSTRACT}

Diabetes Mellitus is recognized as one of the leading causes of death \& disability worldwide. India is in leading position with largest number of Diabetes cases. The physical, social \& economic factors involved in the occurrence \& management of diabetes mellitus. Besides morbidities \& increased health care expenditures, diabetes is related to many catastrophic life-threatening complications such as neuropathy [24.6\%], coronary heart disease [23.6\%], renal disease [21.1\%], retinopathy [16.6\%], foot ulcers [5.5\%], stroke. Similarly, body fat percentage, greater than $25 \%$ in males \& $30 \%$ in females, waist circumference more than $80 \mathrm{~cm}$ in females \& $90 \mathrm{~cm}$ in males is associated with increased of diabetes in Indian population.

Key Words: Gestational diabetes, premature disability and death

\section{ABOUT AUTHORS:}

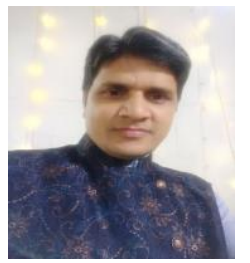

Author Mr. Kailash Chandra Saini is working as Associate Professor, Apex University, Jaipur, Rajasthan, India. He has attended various webinars, seminars and conferences.

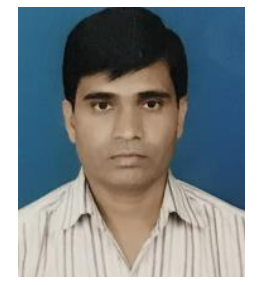

Author Dr. Rajendra Prasad Sharma is working as Associate Professor at Mahatma Gandhi Nursing College Jaipur, Rajasthan, India. He is a Research Guide for PG and Ph.D. Scholar. He has Presented Papers at Various Seminars and Conferences. 


\section{INTRODUCTION}

Diabetes is a chronic disease that occurs when the pancreas does not produce enough insulin, or alternatively, when the body cannot effectively use the insulin it produces. People with impaired glucose tolerance or impaired fasting glucose are at high risk of progressing to type 2 diabetes, although this is not inevitable.

Type 1 diabetes is characterized by a lack of insulin production in the body (Without daily administration of insulin). Type 2 diabetes results from the body's ineffective use of insulin. Type 2 diabetes comprises $90 \%$ of people with diabetes around the world, and is largely the result of excess body weight and physical inactivity. This type of diabetes was seen only in adults but it is now also occurring in obese children. Gestational diabetes is hyperglycemia which is first recognized during pregnancy. Gestational diabetes is most often diagnosed through prenatal screening, rather than reported symptoms.

Diabetes is one of the most frequently occurring chronic diseases in the world affecting nearly $15-20 \%$ of the population (World Health Organization, 2016). Research studies have shown that the progress of diabetes is also associated with a high risk of developing vascular, renal, retinal and neuropathy complications leading to premature disability and death.

Type 2 diabetes is the most common form of diabetes, and affects 85 to 90 per cent of all people with diabetes. While it usually affects mature adults, younger people are also now being diagnosed in greater numbers, as rates of obesity and people being overweight High blood glucose levels over time can cause damage to various parts of the body. These are referred to as diabetes complications.

The diabetic patient should inspect the feet daily for cuts, blisters, redness, and swelling or nail problem. Use a magnifying hand mirror to look at the bottom of the feet.The person with diabetes should do the foot the examination daily. Uses a water-based moisturizer every day to prevent dry skin and cracking. Always cut the nail with a safety clipper, cut them straight and never too short. Diabetic patient should wear comfortable shoes to be sure, one can concern with podiatrist (foot doctor).

The diabetic patient should do the regular exercise to improve the bone and joint health of feet, improve circulation. The diabetic patient should avoid the smoking, because tobacco damages the blood vessels leads to poor circulation.

For controlling the diabetes, patient should take therapeutic diet, medications, check the blood sugar level regularly, exercising regularly and maintain the good communication with the physician.

\section{OBJECTIVES OF THE STUDY}

1 To assess the level of knowledge regarding Diabetic foot care among the diabetic patient.

2 To develop and validate an information booklet on Diabetic foot care

3 To find out the association between knowledge scores and selected demographic variables i.e. age, gender, qualification, duration of illness and occupation.

\section{ASSUMPTIONS}

1. Diabetic patient may have inadequate knowledge about Diabetic foot care.

2. Diabetic patient knowledge regarding diabetic foot care may vary with their selected demographic variables. HYPOTHESIS

- $\mathbf{H}_{\mathbf{1}}$ - There will be significant association between knowledge on diabetic foot care among diabetic patient with their selected demographic variables.

\section{DELIMITATIONS}

- The study is delimited only to diabetes patient in selected hospital.

\section{RESEARCH METHODOLOGY}

- Only knowledge regarding foot care is assessed

A research methodology defines what the activity of research is; how to proceed, how to measure progress \& what constitute success. The methodological paves crucial implications for validity \& credibility of the study findings. Methodology of research indicates the general pattern for organizing the procedure for the empirical study together with the method of obtaining valid \& reliable data for an investigation. 


\section{ARTICLES}

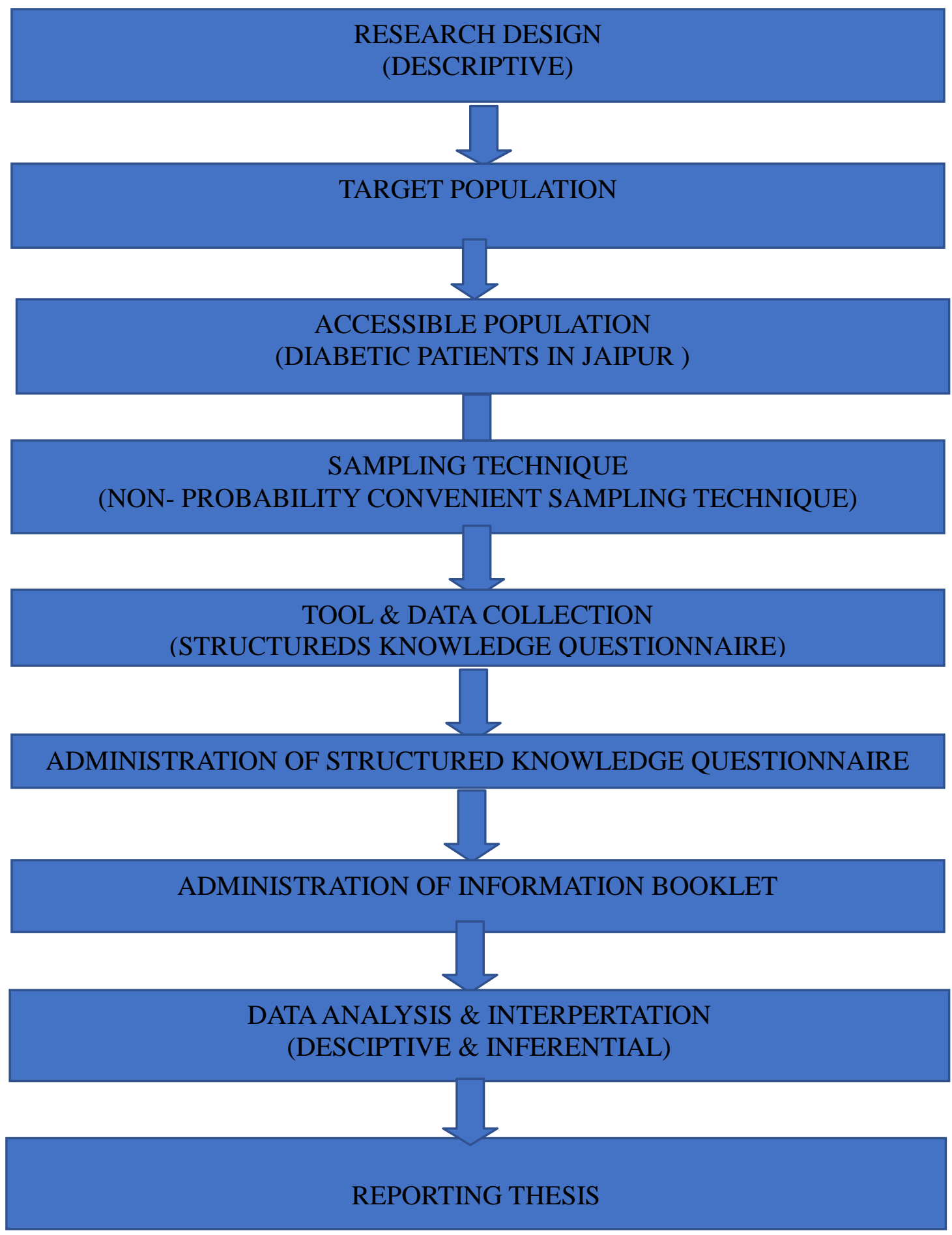

Fig: 1 Schematic Representation of Research methodology

\section{ANALYSIS AND INTERPRETATION}

Analysis is the process of categorizing, ordering, manipulating and summarizing the data to obtain answers to research questions. The purpose of analysis is to reduce data to intelligible and interpretable from the relations of research problems can be studied and tested. 


\section{ARTICLES}

\section{SECTION I ANALYSIS OF DEMOGRAPHIC DATA}

Table -1. It deals with the analysis of the demographic data of the samples

$\mathrm{N}=100$

\begin{tabular}{|c|c|c|c|}
\hline Sr. No. & Demographical data & Frequency & Percentage \\
\hline \multirow[t]{5}{*}{1} & AGE (IN YEARS) & & \\
\hline & $20-30$ years & 13 & 13.0 \\
\hline & $31-40$ years & 17 & 17.0 \\
\hline & $41-50$ years & 48 & 48.0 \\
\hline & Above 50 & 22 & 22.0 \\
\hline \multirow[t]{3}{*}{2} & Gender & & \\
\hline & Male & 58 & 58.0 \\
\hline & Female & 42 & 42.0 \\
\hline \multirow[t]{6}{*}{3} & EDUCATION & & \\
\hline & Illiterate & 14 & 14.0 \\
\hline & Primary & 16 & 16.0 \\
\hline & Higher Secondary & 5 & 5.0 \\
\hline & Graduate & 44 & 44.0 \\
\hline & Post Graduate & 21 & 21.0 \\
\hline \multirow[t]{5}{*}{4} & Family income & & \\
\hline & 5000-10000 Rs/month & 12 & 12.0 \\
\hline & 10001-15000 Rs/month & 17 & 17.0 \\
\hline & 15001-20000 Rs/month & 45 & 45.0 \\
\hline & Above 20000 Rs/month & 26 & 26.0 \\
\hline \multirow[t]{5}{*}{5} & Religion & & \\
\hline & Hindu & 65 & 65.0 \\
\hline & Muslim & 30 & 30.0 \\
\hline & Christian- & 3 & 3.0 \\
\hline & Others (Specify) & 2 & 2.0 \\
\hline \multirow[t]{5}{*}{6} & Marital Status & & \\
\hline & Single & 18 & 18.0 \\
\hline & Married & 62 & 62.0 \\
\hline & Divorced & 5 & 5.0 \\
\hline & Separated & 15 & 15.0 \\
\hline \multirow[t]{5}{*}{7} & Occupation & & \\
\hline & Labour & 21 & 21.0 \\
\hline & Government Services & 41 & 41.0 \\
\hline & Self-Work/ Private Service & 15 & 15.0 \\
\hline & Other & 23 & 23.0 \\
\hline \multirow[t]{8}{*}{8} & Diabetic Foot care Awareness Programme & & \\
\hline & Yes & 20 & 20.0 \\
\hline & No & 80 & 80.0 \\
\hline & If, yes -20 & & \\
\hline & New Papers & 9 & 45.0 \\
\hline & Conference/Seminar & 8 & 40.0 \\
\hline & Television & 3 & 15.0 \\
\hline & Radio & 0 & 0 \\
\hline
\end{tabular}




\section{ARTICLES}

\begin{tabular}{|l|l|c|c|}
\hline Sr. No. & Demographical data & Frequency & Percentage \\
\hline 9 & Period of Diabetic & & \\
\hline & Less than 10 years & 46 & 46.0 \\
\hline & More than 10 years & 54 & 54.0 \\
\hline
\end{tabular}

\section{SECTION-II-DESCRIPTION AND ANALYSIS OF STRUCTURED KNOWLEDGE QUESTIONNAIRE REGARDING}

DIABETIC FOOT CARE

This section deals with the analysis and interpretation of the data related to knowledge of diabetic foot care. This helps in identifying the deficiencies in knowledge and to decide the priority needs of the diabetic foot care.

Knowledge scores of diabetic foot care were obtained by administering a structured knowledge questionnaire.

(a) FREQUENCY AND PERCENTAGE DISTRIBUTION OF KNOWLEDGE SCORE REGARDING DIABETIC FOOT CARE.

Table-2.1: Frequency and percentage distribution of knowledge score regarding diabetic foot care.

$\mathrm{N}=100$

\begin{tabular}{|l|l|l|l|}
\hline S.no & Level of Knowledge & F & \% \\
\hline 1 & Inadequate & 55 & 55.0 \\
\hline 2 & Moderate & 25 & 25.0 \\
\hline 3 & Adequate & 20 & 20.0 \\
\hline & & 100 & 100.0 \\
\hline
\end{tabular}

(b) DESCRIPTION OF ASPECT WISE ANALYSIS OF KNOWLEDGE REGARDING DIABETIC FOOT CARE.

Table 2.2 Aspect wise analysis of knowledge regarding diabetic foot care

\begin{tabular}{|l|l|l|l|}
\hline Aspects of Knowledge & No. Of questions & Mean score & $\begin{array}{l}\text { Standard } \\
\text { Deviation }\end{array}$ \\
\hline $\begin{array}{l}\text { Items on knowledge regarding di } \\
\text { and diabetic foot }\end{array}$ & 12 & 6.14 & 1.61 \\
\hline $\begin{array}{l}\text { Items on knowledge regarding } \\
\text { diabetic foot care }\end{array}$ & 18 & 7.51 & 1.87 \\
\hline $\begin{array}{l}\text { Total knowledge score regarding } \\
\text { diabetic foot care }\end{array}$ & 30 & 13.65 & 3.48 \\
\hline
\end{tabular}

SECTION III ANALYSIS OF DATA TO FIND AN ASSOCIATION BETWEEN KNOWLEDGE SCORE OF THE DIABETIC FOOT CARE WITH THEIR DEMOGRAPHIC VARIABLES [ AGE, GENDER, MARITAL STATUS, RELIGION, EDUCATION, OCCUPATION, INCOME, SOURCE OF INFORMATION, DURATION OF DIABETES]

This section deals with an association between knowledge score of the diabetic foot care with their demographic variables. It was associated by using chi square test. 


\section{ARTICLES}

Table 3: Association between knowledge score of the diabetic foot care with their demographic variable

\begin{tabular}{|c|c|c|c|c|c|c|c|c|c|}
\hline \multicolumn{10}{|c|}{$\mathrm{N}=100$} \\
\hline S. No. & Demographic variables & $\mathbf{F}$ & Poor & Average & Good & $\begin{array}{l}\text { Chi. } \\
\text { square }\end{array}$ & d.f. & $\begin{array}{l}\text { Table } \\
\text { value }\end{array}$ & Remark \\
\hline \multirow[t]{8}{*}{1} & AGE (IN YEARS) & & & & & & & & \\
\hline & $20-30$ years & 13 & 8 & 1 & 4 & 9.455 & 6 & 12.591 & NS \\
\hline & & & $61.5 \%$ & $7.7 \%$ & $30 . \%$ & & & & \\
\hline & $31-40$ years & 17 & 11 & 4 & 2 & & & & \\
\hline & & & $64.7 \%$ & $23.5 \%$ & $11 . \%$ & & & & \\
\hline & $41-50$ years & 48 & 28 & 14 & 6 & & & & \\
\hline & & & $58.3 \%$ & $29.2 \%$ & $12 . \%$ & & & & \\
\hline & Above 50 & 22 & 8 & 6 & 8 & & & & \\
\hline \multirow[t]{5}{*}{2} & GENDER & & & & & & & & \\
\hline & Male & 58 & 28 & 17 & 13 & 2.564 & 2 & 5.278 & NS \\
\hline & & & $48.3 \%$ & $29.3 \%$ & $22 . \%$ & & & & \\
\hline & Female & 42 & 27 & 8 & 7 & & & & \\
\hline & & & $64.3 \%$ & $19.0 \%$ & $16 . \%$ & & & & \\
\hline \multirow[t]{11}{*}{3} & EDUCATION & & & & & & & & \\
\hline & Illiterate & 14 & 12 & 0 & 2 & 17.27 & 8 & .027 & Sig \\
\hline & & & $85.7 \%$ & $0.0 \%$ & $14 . \%$ & & & & \\
\hline & Primary & 16 & 9 & 6 & 1 & & & & \\
\hline & & & $56.3 \%$ & $37.5 \%$ & $6.3 \%$ & & & & \\
\hline & Higher Secondary & 5 & 3 & 1 & 1 & & & & \\
\hline & & & $60.0 \%$ & $20.0 \%$ & $20 . \%$ & & & & \\
\hline & Graduate & 44 & 20 & 16 & 8 & & & & \\
\hline & & & $45.5 \%$ & $36.4 \%$ & $18 . \%$ & & & & \\
\hline & Post Graduate & 21 & 11 & 2 & 8 & & & & \\
\hline & & & $52.4 \%$ & $9.5 \%$ & $38 . \%$ & & & & \\
\hline \multirow[t]{8}{*}{4} & FAMILY INCOME & & & & & & & & \\
\hline & 5000-10000Rs/month & 12 & 12 & 0 & 0 & 13.045 & 6 & 12.591 & Sig \\
\hline & & & $100 . \%$ & $0.0 \%$ & $0.0 \%$ & & & & \\
\hline & 10001-15000 P.M & 17 & 10 & 3 & 4 & & & & \\
\hline & & & $58.8 \%$ & $17.6 \%$ & $23 . \%$ & & & & \\
\hline & 15001-20000 P.M. & 45 & 22 & 14 & 9 & & & & \\
\hline & & & $48.9 \%$ & $31.1 \%$ & $20 . \%$ & & & & \\
\hline & More than 20001 P.M. & 26 & 11 & 8 & 7 & & & & \\
\hline
\end{tabular}




\section{ARTICLES}

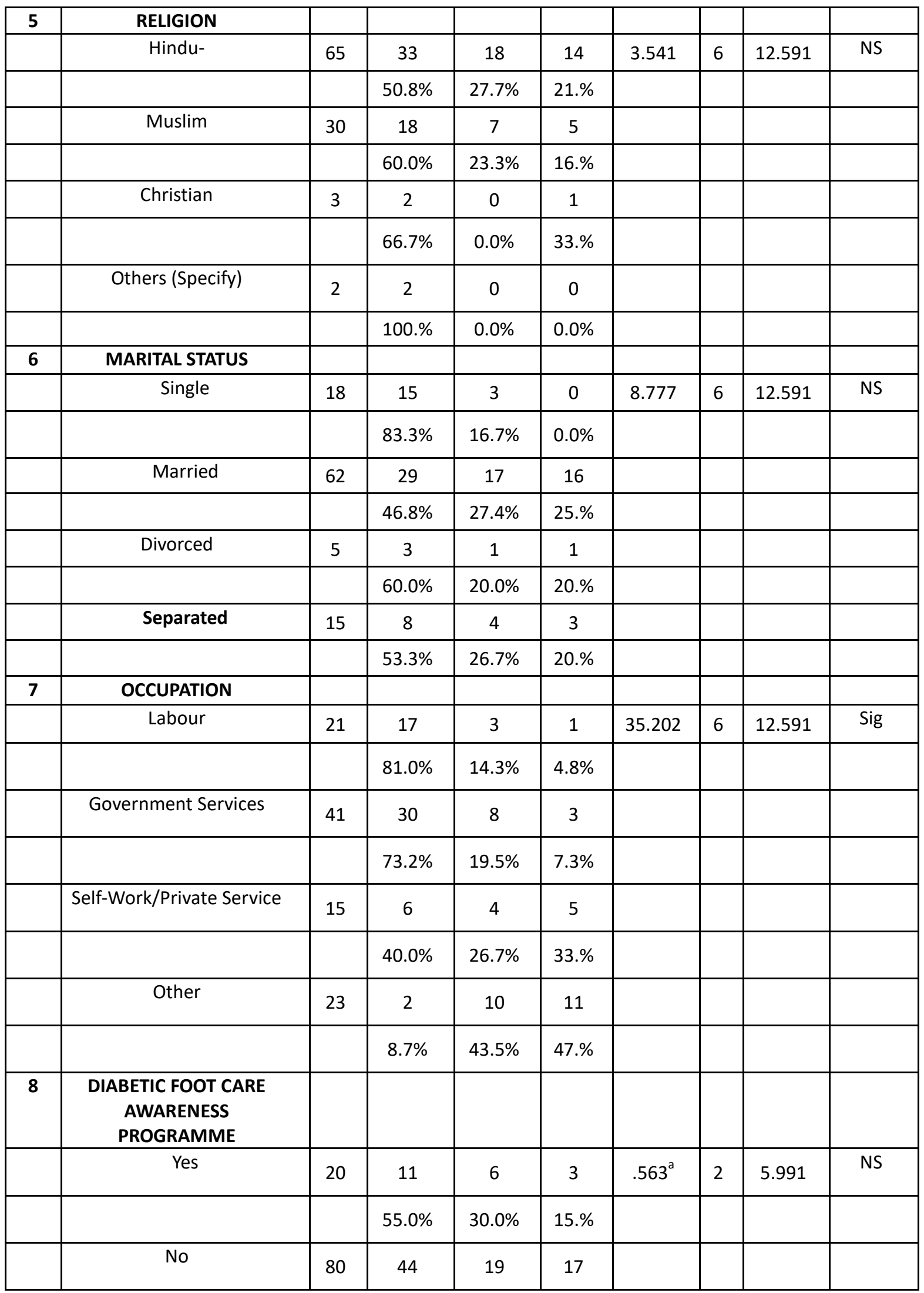




\section{ARTICLES}

\begin{tabular}{|c|c|c|c|c|c|c|c|c|c|}
\hline & & & & & & & & & \\
\hline $8 \mathrm{a}$ & If, yes & & & & & & & & \\
\hline & New Papers & 9 & 5 & 2 & 2 & $4.444^{\mathrm{a}}$ & 4 & 7.448 & NS \\
\hline & & & $55.6 \%$ & $22.2 \%$ & $22 . \%$ & & & & \\
\hline & Conference/Seminar & 8 & 4 & 4 & 0 & & & & \\
\hline & & & $50.0 \%$ & $50.0 \%$ & $0.0 \%$ & & & & \\
\hline & Television & 3 & 2 & 0 & 1 & & & & \\
\hline & & & $66.7 \%$ & $0.0 \%$ & $33 . \%$ & & & & \\
\hline & Radio & & & & & & & & \\
\hline 9 & PERIOD OF DIABETIC & & & & & & & & \\
\hline & Less than 10 years & 45 & 30 & 6 & 9 & $6.479^{\mathrm{a}}$ & 2 & 5.991 & Sig \\
\hline & & & $66.7 \%$ & $13.3 \%$ & $20 . \%$ & & & & \\
\hline & More than 10 years & 55 & 25 & 19 & 11 & & & & \\
\hline & & & $45.5 \%$ & $34.5 \%$ & $20 . \%$ & & & & \\
\hline
\end{tabular}

\section{CONCLUSION}

The purpose of the study was to assess the knowledge Regarding Foot Care among the Diabetes Patient in selected Hospitals at Jaipur in view to develop information booklet. The whole study was cost effective, simple \& carried out in an acceptable way to assess the level of knowledge. The result shows that the diabetic foot patients had moderately adequate knowledge regarding diabetic foot care, hence the researcher felt the need to develop an information booklet to enhance their knowledge in related area.

\section{REFERENCES}

1. G.N.Prabakar, "Text Book of Community health for Nurses", 1 st Edition, Delhi,2004.PP 205-207.

2. Porth Matterson Carol, "Essentials of Pathophysiology Concepts of Altered Health Status", $6{ }^{\text {th }}$ Edition; Lippincott Williams and Wilkins Publishers, Philadelphia, (2004): 191-230 PP.

3. Dr.Baride J.P,Kulkarni A.P, “Text book of medicine" $3^{\text {rd }}$ Edition, Vora Medical Publications, Mumbai,2006:PP 497

4. World health organization, "Preventing and Managing the Global Epideric", Report of a WHO Consultation on obesity; Geneva, Switzerland (1997)

5. Ghai .O.P Gupta, "Text book of Preventive and Social Medicines", $2^{\text {nd }}$ Edition; CBS Publishers, New Delhi, (2002); 456-463. 